\title{
Alterations of Bio-elements, Oxidative, and Inflammatory Status in the Zinc Deficiency Model in Rats
}

\author{
Urszula Doboszewska ${ }^{1}$ - Bernadeta Szewczyk ${ }^{1} \cdot$ Magdalena Sowa-Kućma $^{1}$ • \\ Karolina Noworyta-Sokołowska ${ }^{1} \cdot$ Paulina Misztak $^{1,2} \cdot$ Joanna Gołębiowska $^{1}$. \\ Katarzyna Młyniec ${ }^{2} \cdot$ Beata Ostachowicz $^{3} \cdot$ Mirosław Krośniak ${ }^{2}$ • \\ Agnieszka Wojtanowska-Krośniak ${ }^{2} \cdot$ Krystyna Gołembiowska $^{1}$ • \\ Marek Lankosz ${ }^{3}$. Wojciech Piekoszewski ${ }^{4}$ - Gabriel Nowak ${ }^{1,2}$
}

Received: 20 September 2015/Revised: 26 October 2015/Accepted: 28 October 2015/Published online: 18 November 2015 (C) The Author(s) 2015. This article is published with open access at Springerlink.com

\begin{abstract}
Our previous study showed that dietary zinc restriction induces depression-like behavior with concomitant up-regulation of the $\mathrm{N}$-methyl-D-aspartate receptor (NMDAR). Because metal ions, oxidative stress, and inflammation are involved in depression/NMDAR function, in the present study, bio-elements (zinc, copper, iron, magnesium, and calcium), oxidative (thiobarbituric acidreactive substances; protein carbonyl content), and inflammatory (IL-1 $\alpha$, IL-1 $\beta$ ) factors were measured in serum, hippocampus (Hp), and prefrontal cortex (PFC) of male Sprague-Dawley rats subjected to a zinc-adequate (ZnA) $(50 \mathrm{mg} \mathrm{Zn/kg)} \mathrm{or} \mathrm{a} \mathrm{zinc-deficient} \mathrm{(ZnD)}(3 \mathrm{mg} \mathrm{Zn/}$ $\mathrm{kg}$ ) diet for 4 or 6 weeks. Both periods of dietary zinc restriction reduced serum zinc and increased serum iron levels. At 4 weeks, lowered zinc level in the PFC and Hp as well as lowered iron level in the PFC of the $\mathrm{ZnD}$ rats was observed. At 6 weeks, however, iron level was increased in the PFC of these rats. Although at 6 weeks zinc level in the PFC did not differ between the $\mathrm{ZnA}$ and $\mathrm{ZnD}$ rats, extracellular zinc concentration after $100 \mathrm{mM}$ $\mathrm{KCl}$ stimulation was reduced in the $\mathrm{PFC}$ of the $\mathrm{ZnD}$ rats and was accompanied by increased extracellular iron and
\end{abstract}

Urszula Doboszewska

u.doboszewska@wp.pl; doboszew@if-pan.krakow.pl

1 Institute of Pharmacology, Polish Academy of Sciences, Smętna 12, 31-343 Kraków, Poland

2 Faculty of Pharmacy, Jagiellonian University Medical College, Medyczna 9, 30-688 Kraków, Poland

3 Faculty of Physics and Applied Computer Sciences, AGH University of Science and Technology, Mickiewicza 30, 30-059 Kraków, Poland

4 Faculty of Chemistry, Jagiellonian University, Ingardena 3, 30-060 Kraków, Poland glutamate levels (as measured by the in vivo microdialysis). The examined oxidative and inflammatory parameters were generally enhanced in the tissue of the $\mathrm{ZnD}$ animals. The obtained data suggest dynamic redistribution of bioelements and enhancement of oxidative/inflammatory parameters after dietary zinc restriction, which may have a link with depression-like behavior/NMDAR function/ neurodegeneration.

Keywords Zinc deficiency - Zinc · Iron · Oxidation · Inflammation · Glutamate

\section{Introduction}

Zinc is the second (after iron) most prevalent trace element in the human body. Its importance has been demonstrated in many physiological processes. Zinc is crucial for normal development and function of cell-mediated immunity. Zinc deficiency primarily has an impact on $T$ cells function and affects Th1 and (to a lesser extend) Th2 cytokines production (Bonaventura et al. 2015). Zinc deficiency influences also production of interleukin (IL)-1 $\beta$ by macrophages (Bonaventura et al. 2015). IL-1 $\beta$ plays a key role in the damaging inflammatory response in a variety of diseases (Dinarello et al. 2012). Altered production of cytokines during zinc deficiency may lead to inflammation, e.g., zinc depletion from macrophages induces IL-1 $\beta$ secretion and activates NLRP3 inflammasome (Summersgill et al. 2014). Moreover, zinc which is (in contrast to iron) redox inactive metal, serves as an important component of antioxidant defense. It contributes to maintaining redox balance through different mechanisms, e.g., is an inhibitor of nicotinamide adenine dinucleotide phosphate (NADPH) oxidase, a co-factor of superoxide dismutase 
(SOD), and induces the generation of cysteine-rich metallothionein, which acts as scavenger of oxidants (Oteiza 2012; Prasad 2014). In contrast, zinc deficiency is associated with increased oxidative stress markers (Prasad 2014).

There is evidence for the involvement of inflammation and oxidative stress in depression (Leonard and Maes 2012; Maes et al. 2012a; Moylan et al. 2014). Depressed patients exhibit increased levels of pro-inflammatory cytokines, e.g., IL-1 $\beta$, whereas administration of these cytokines (including IL-1 $\beta$ ) induces depression-like behavior in experimental animals (Maes et al. 2012a). Both preclinical and clinical data indicate also that depression is accompanied by increased lipid, protein, and DNA peroxidation (Siwek et al. 2013a). Oxidative stress and inflammation may contribute to depression through effects on the glutamatergic system (Marsden 2011). Pro-inflammatory cytokines, such as IL-1 $\beta$, and reactive oxygen species can enhance the activity of indoleamine 2,3-dioxygenase (IDO), an enzyme which catabolizes tryptophan, the primary precursor of serotonin, into kynurenine, which is further broken down into kynurenic acid and quinolinic acid. While kynurenic acid is the ionotropic glutamate $\mathrm{N}$ methyl-D-aspartate receptor (NMDAR) endogenous antagonist, quinolinic acid is a strong agonist of NMDAR (Leonard and Maes 2012; Maes et al. 2012a; Felger and Lotrich 2013; Myint and Kim 2014). Therefore, inflammation and oxidative stress via activation of IDO pathway may lead to abnormal regulation of glutamate transmission through NMDAR, a phenomenon implicated in the pathophysiology of depression (Sanacora et al. 2012; Ghasemi et al. 2014). Moreover, a mixture of pro-inflammatory cytokines, containing IL-1 $\beta$, was shown to increase glutamate release (Ida et al. 2008). This observation provides another route by which cytokines may influence the glutamatergic system and conceivably lead to depression.

In addition to oxidative/inflammatory status, NMDAR is a subject to modulation by a number of agents including metal ions (Szewczyk et al. 2012). At resting membrane potential magnesium blocks NMDAR channel, prohibiting calcium influx. Depletion of magnesium block during depolarization allows calcium to enter the postsynaptic neuron. Under certain conditions, magnesium and calcium can block/permeate the channel (Mayer and Westbrook 1987). Zinc is a potent inhibitor of NMDAR (Paoletti et al. 2009). Also copper and iron were found to inhibit this receptor (Vlachova et al. 1996; Nakamichi et al. 2002; Stys et al. 2012). Of note, relationships between altered homeostasis of bio-elements as well as increased oxidative/inflammatory status and NMDAR function were implicated in depressive disorders (Marsden 2011; Leonard and Maes 2012; Serefko et al. 2013; Mlyniec et al. 2014a, 2015).

Recently, a low dietary zinc intake emerged as a risk factor for depression (Vashum et al. 2014). Zinc deficiency is regarded as a public health problem (Jurowski et al. 2014). It induces psychopathological symptoms that correspond to depression symptoms (Szewczyk 2013; Hagmeyer et al. 2015). We have previously shown that depression-like behavior induced by dietary zinc restriction in rats is associated with up-regulation of NMDAR in brain regions (hippocampus, $\mathrm{Hp}$ and prefrontal cortex, PFC) (Doboszewska et al. 2015). Because alterations of metals as well as oxidative/inflammatory status may be linked to abnormal NMDAR function and depression, here we measured bio-elements (zinc, copper, calcium, magnesium, and iron) and oxidation/inflammation parameters (thiobarbituric acid-reactive substances (TBARS), protein carbonyl content (PCC), IL- $1 \alpha$ and IL-1 $\beta$ ) in serum, the Hp and PFC of rats following a zinc-deficient $(\mathrm{ZnD})$ diet administration. Moreover, extracellular zinc, iron, and glutamate levels were measured.

\section{Materials and Methods}

\section{Animals and Diet}

All procedures were conducted according to the National Institutes of Health Animal Care and Use Committee guidelines and were approved by the Ethics Committee of the Institute of Pharmacology, Krakow. In the study, 40 male Sprague-Dawley rats (Charles River Laboratories, Erkrath, Germany) were used that were delivered at the age of 4 weeks. Upon arrival, the rats were habituated to the laboratory conditions for 1 week. During the habituation phase, the rats were fed a standard diet with $35 \mathrm{mg} \mathrm{Zn} / \mathrm{kg}$. Following the habituation phase, the animals were divided into 4 groups; each group consisted of $n=10$ rats that were fed a zinc-adequate $(\mathrm{ZnA})$ diet of $50 \mathrm{mg} \mathrm{Zn} / \mathrm{kg}$ or a $\mathrm{ZnD}$ diet of $3 \mathrm{mg} \mathrm{Zn} / \mathrm{kg}$, for 4 or 6 weeks. Detailed specification of elements: zinc, copper, calcium, magnesium and iron for the $\mathrm{ZnA}$ and $\mathrm{ZnD}$ diets is provided in Table 1. The diets were purchased from Altromin $\mathrm{GmbH}$ (Lage, Germany). The animals were housed 5 per cage in a controlled environment (temperature $22 \pm 2{ }^{\circ} \mathrm{C}, 12 \mathrm{~h}$

Table 1 The amounts of bio-elements: zinc $(\mathrm{Zn})$, copper $(\mathrm{Cu})$, calcium $(\mathrm{Ca})$, magnesium $(\mathrm{Mg})$, and iron $(\mathrm{Fe})$ in the zinc-adequate $(\mathrm{ZnA})$ and zinc-deficient $(\mathrm{ZnD})$ diets

\begin{tabular}{llll}
\hline & Units & ZnA diet & ZnD diet \\
\hline $\mathrm{Zn}$ & $\mathrm{mg} / \mathrm{kg}$ & 50 & 3 \\
$\mathrm{Cu}$ & $\mathrm{mg} / \mathrm{kg}$ & 5 & 5 \\
$\mathrm{Ca}$ & $\mathrm{mg} / \mathrm{kg}$ & 9482 & 9513 \\
$\mathrm{Mg}$ & $\mathrm{mg} / \mathrm{kg}$ & 709 & 716 \\
$\mathrm{Fe}$ & $\mathrm{mg} / \mathrm{kg}$ & 179 & 179 \\
\hline
\end{tabular}


light/dark cycle, 40-50\% humidity) with free access to food and water. The body weight of each rat was measured weekly. Additional group $(n=9)$ of a 4-week male Sprague-Dawley rats (Charles River Laboratories) was used in the in vivo microdialysis study. Before the in vivo microdialysis, the rats were applied a 6-week diet regimen. Briefly, following a 1-week habituation period, the rats were divided into groups $(n=4-5)$ that received a $\mathrm{ZnA}$ or a $\mathrm{ZnD}$ diet for 6 weeks.

\section{Tissue Processing}

Following 4 or 6 weeks of the $\mathrm{ZnA}$ or $\mathrm{ZnD}$ diet, the rats were killed by rapid decapitation; their brains were rapidly dissected and immersed in cooled $\left(2-8{ }^{\circ} \mathrm{C}\right) 0.9 \%$ sodium chloride $(0.9 \% \mathrm{NaCl})$ solution. Complete hippocampus (Hp) (dorsal and ventral) and prefrontal cortex (PFC) were dissected on a cold plate, immediately frozen on dry ice and stored at $-80{ }^{\circ} \mathrm{C}$ until further analysis. The trunk blood was collected into tubes without anti-coagulant. The blood was allowed to clot for 15-20 min and was centrifuged for $30 \mathrm{~min}$ at $1800 \mathrm{rpm}$ at $4{ }^{\circ} \mathrm{C}$. The resulting supernatant (serum) was quickly pipetted into tubes that were stored at $-80{ }^{\circ} \mathrm{C}$ until analysis.

\section{Total Reflection X-Ray Fluorescence}

Zinc, copper, and iron concentrations were measured in serum, the $\mathrm{Hp}$, and PFC using total reflection X-ray fluorescence (TXRF) method, as described previously (Opoka et al. 2010). The Hp and PFC were weighted and digested in $100-300 \mu \mathrm{L}$ (depending on the mass of the sample) of the concentrated nitric acid. As an internal standard, selenium standard was added, so that the final concentration was $5 \mathrm{mg} / \mathrm{l}$ for serum and $30-50 \mathrm{mg} / \mathrm{kg}$ for brain tissues. From the resulting solutions, $5 \mu \mathrm{l}$ was pipetted on reflectors made of clean glass used for TXRF analysis. Concentrated nitric acid, suprapur quality, additionally cleaned by subboiling distillation procedure, was purchased from Merck (Darmstadt, Germany). Selenium standard, 1000 mg/l selenium in nitric acid, was purchased from Sigma-Aldrich (Saint Louis, Missouri, United States). NANOHUNTER TXRF Spectrometer from Rigaku (Japan) was used. Mo $\mathrm{X}$-ray tube $(50 \mathrm{kV}, 0.8 \mathrm{~mA})$ was applied. The results are presented in $\mathrm{mg} / \mathrm{l}$ (for serum) or $\mathrm{mg} / \mathrm{kg}$ wet weight of brain tissue.

\section{Flame Atomic Absorption Spectroscopy}

Calcium and magnesium concentrations were measured in serum, the $\mathrm{Hp}$, and PFC using flame atomic absorption spectroscopy, as published previously (Kopanski et al. 2000). The Hp and PFC were weighted (0.018-0.198 g) and digested in $1.5 \mathrm{ml}$ of concentrated nitric acid (SupraPur-Merck). Brain tissue samples were mineralized using water bath for $5 \mathrm{~h}$ at $80^{\circ} \mathrm{C}$. After cooling the samples, demineralized water was added to the total volume of $5 \mathrm{ml}$. Magnesium was measured at wavelength of $285.2 \mathrm{~nm}$ and calcium at $422.7 \mathrm{~nm}$, both with deuterium (D2) background correction. The results are presented in $\mathrm{mg} / \mathrm{l}$ (for serum) or $\mathrm{mg} / \mathrm{kg}$ wet weight of brain tissue.

\section{Endocrine, Oxidative Stress, and Inflammation Assays}

Serum corticosterone (CORT), oxidative, and inflammatory parameters were measured using commercially available kits, according to the manufacturer's protocols. Serum CORT concentration was determined by enzyme-linked immunoassay (ELISA) using Corticosterone Rat/Mouse Elisa Kit (Demeditec Diagnostics GmbH, Kiel, Germany). The levels of lipid and protein peroxidation were measured in serum, the Hp, and PFC using thiobarbituric acid-reactive substances (TBARS) Assay kit or Protein Carbonyl Colorimetric Assay Kit (Cayman Chemical, Ann Arbor, MI, USA), respectively. To determine lipid peroxidation, the malondialdehyde (MDA)-thiobarbituric acid (TBA) adduct was measured fluorometrically at an excitation wavelength of $530 \mathrm{~nm}$ and an emission wavelength of $550 \mathrm{~nm}$. The levels of IL- $1 \alpha$ and IL-1 $\beta$ were measured in serum, the Hp, and PFC using Rat IL- $1 \alpha$ or Il-1 $\beta$ ELISA kit (RayBiotech, Norcross, GA, USA).

\section{In Vivo Microdialysis}

Following 6 weeks of the $\mathrm{ZnA}$ or $\mathrm{ZnD}$ diet, in vivo microdialysis was performed. Five days before the microdialysis, the rats were anesthetized with chloral hydrate (400 mg/kg) and individually placed in a stereotaxic apparatus (David Kopf Instruments, Tujunga, CA, USA). Their skull was exposed, a burr hole was drilled, and a guide cannula (AgnTho's, Sweden) was implanted in the rat $\mathrm{PFC}$ with coordinates: $\mathrm{AP}=+2.8 ; L=+0.8$; $V=-2.4$, based on the brain atlas (Paxinos and Watson 1998). The guide cannula was secured with dental cement (Dentalon; Heraeus-Kulzer GmbH, Germany) and a screw. After the surgical operation, each rat was housed individually. Five days after implantation of the guide cannula, a microdialysis probe $(3 \mathrm{~mm}$, AgnTho's, Sweden) was inserted into the PFC through the guide cannula. The microdialysis probe was connected with the microdialysis pump, which infused an artificial cerebrospinal fluid (aCSF) containing $147 \mathrm{mM} \mathrm{NaCl}, 4.0 \mathrm{mM} \mathrm{KCl}, 1.0 \mathrm{mM}$ $\mathrm{MgCl}_{2}, 2.2 \mathrm{CaCl}_{2}$, and $\mathrm{pH}=7.4$ with a flow of $2 \mu \mathrm{l} / \mathrm{min}$. After a $2 \mathrm{~h}$ washout period, the fractions were collected for $2 \mathrm{~h}$ (to determine the basal extracellular concentrations of 
zinc, iron, and glutamate). Then, the PFC was perfused with $100 \mathrm{mM} \mathrm{KCl}$ in Ringer's solution for $40 \mathrm{~min}$, and the fractions were collected every $20 \mathrm{~min}$ (to determine the extracellular concentrations of zinc, iron, and glutamate after depolarization).

\section{Analytical Procedures: Microdialysates}

The extracellular concentrations of zinc and iron were measured by TXRF method using selenium standard, as described above. The extracellular concentration of glutamate was measured after derivatization with OPA/sulfite reagent. OPA/sulfite glutamate derivative was analyzed using high-performance liquid chromatography (HPLC) method with electrochemical detection. Chromatography was performed using Dionex P580 pump (USA), an LC 4B amperometric detector with a cross-flow detector cell (BAS, IN, USA), and a HR- 80 column $(4 \times 80 \mathrm{~mm}, 3 \mu \mathrm{m}$; ESA, USA). The mobile phase consisted of $0.1 \mathrm{M}$ phosphate buffer with $\mathrm{pH} 3.6$ and $5 \%$ methanol. The flow rate was $0.8 \mathrm{ml} / \mathrm{min}$, and the applied potential of 3-mm glassy carbon electrode was $+650 \mathrm{mV}$ at a sensitivity of $5 \mathrm{nA} / \mathrm{V}$. Glutamate derivative concentration was calculated by comparing its peak area with respective standard and was processed by Chromax 2005 (Pol-Lab, Warsaw, Poland) software run on a personal computer.

\section{Statistics}

Data were analyzed using unpaired, two-tailed Student's $t$ test or Repeated Measures ANOVA followed by a Bonferroni post hoc test. All results are presented as the mean \pm SEM. $P<0.05$ was considered statistically significant with $95 \%$ confidence (Prism ver. 4, GraphPad Software, San Diego, CA, USA).

\section{Results}

\section{The Effects of Dietary Zinc Restriction on Body Weight}

During the zinc regimen, the rats displayed a typical early sign of zinc deficiency of growth retardation (Prasad 2012). A gradual increase in body weight in both groups in the course of time was observed, but the body weight was significantly reduced in rats fed the $\mathrm{ZnD}$ diet for 4 weeks, compared to rats fed the ZnA diet, in the second, third, and fourth weeks (Fig. 1a). The body weight was also significantly reduced in rats fed the $\mathrm{ZnD}$ diet for 6 weeks. This effect emerged in the second week and persisted to the sixth week (Fig. 1b).
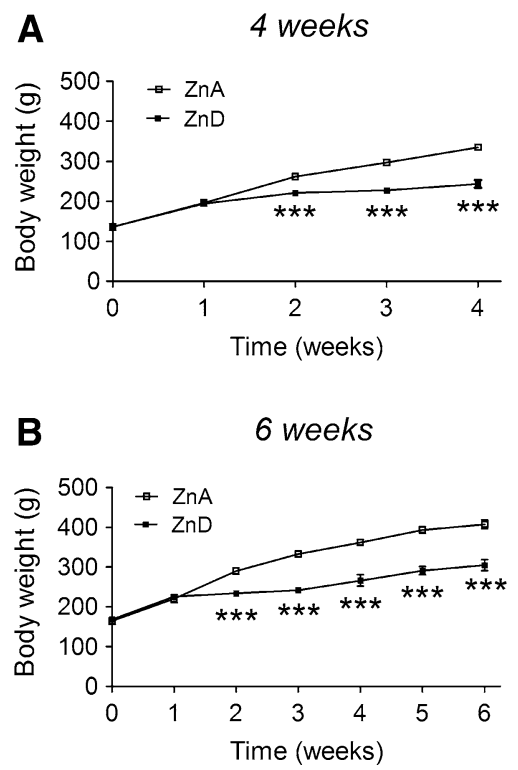

Fig. 1 The effects of a 4-week a or a 6-week, b dietary zinc restriction on body weight. Rats were fed a zinc-adequate $(\mathrm{ZnA}) \operatorname{diet}$ $(50 \mathrm{mg} \mathrm{Zn} / \mathrm{kg})$ or a zinc-deficient $(\mathrm{ZnD}) \operatorname{diet}(3 \mathrm{mg} \mathrm{Zn} / \mathrm{kg})$ for 4 or 6 weeks. Values are expressed as the mean \pm SEM, $n=10$ per group. Repeated measures ANOVA demonstrated a significant interaction $[F(4,72)=52.51, p<0.0001]$, a significant effect of the $\operatorname{diet}[F(1,18)=58.72, p<0.0001]$ and a significant effect of time $[F(4,72)=464.16, p<0.0001]$ on body weight following a 4-week $\mathrm{ZnD}$ diet. Repeated measures ANOVA demonstrated a significant interaction $[F(6,108)=31.09, p<0.0001]$, a significant effect of the diet $[F(1,108)=49.41, p<0.0001]$, and a significant effect of time $[F(6,108)=240.09, p<0.0001]$ on body weight following a 6 -week $\mathrm{ZnD}$ diet. $* * * p<0.001$ versus respective $\mathrm{ZnA}$ (Bonferroni post hoc test)

The Effects of a 4-week Dietary Zinc Restriction on $\mathrm{Zn}, \mathrm{Cu}, \mathrm{Ca}, \mathrm{Mg}, \mathrm{Fe}$, CORT, TBARS, and PCC Levels in Serum

A 4-week $\mathrm{ZnD}$ diet significantly decreased serum zinc (Fig. 2a) and calcium (Fig. 2c) concentrations, increased magnesium (Fig. 2d) and iron (Fig. 2e) concentrations but did not affect serum copper concentration (Fig. 2b). Moreover, a $4-\mathrm{ZnD}$ diet significantly increased serum CORT (Fig. 2f) and PCC (Fig. 2h) concentrations but decreased TBARS concentration (Fig. 2g).

\section{The Effects of a 4-week Dietary Zinc Restriction on $\mathrm{Zn}, \mathrm{Cu}, \mathrm{Ca}, \mathrm{Mg}$, Fe, TBARS, PCC, IL-1 $\alpha$, and IL- $1 \beta$ Levels in the Hp and PFC}

A 4-week $\mathrm{ZnD}$ diet significantly decreased zinc levels in the Hp (Fig. 3a) and PFC (Fig. 3f) of rats. In addition, decreased iron level was observed in the PFC (Fig. 3j), but not in the Hp (Fig. 3e) of the $\mathrm{ZnD}$ rats. At 4 weeks, the levels of copper did not significantly differ in the $\mathrm{Hp}$ 


\section{4 weeks - serum}

A
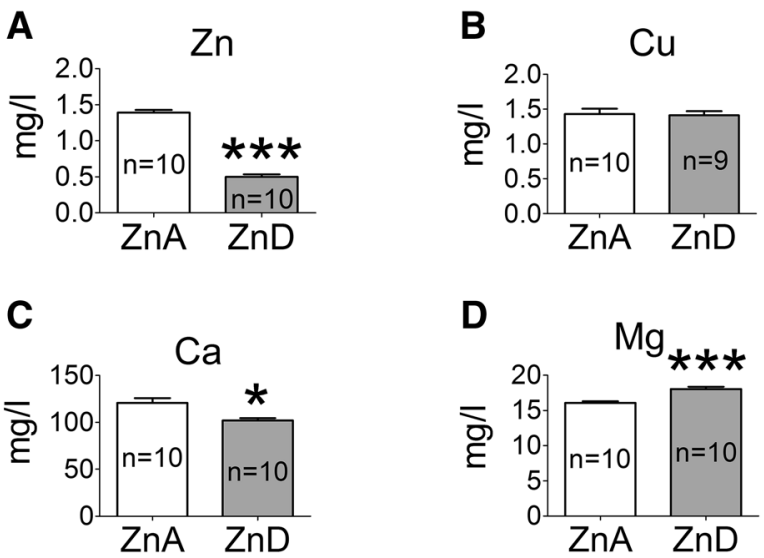

E
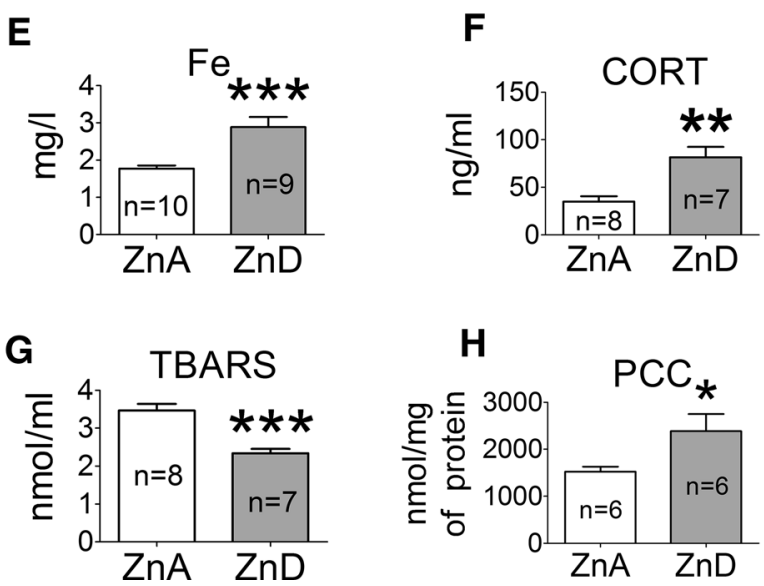

Fig. 2 The effects of a 4-week dietary zinc restriction on zinc ( $\mathrm{Zn})$ (a), copper $(\mathrm{Cu})(\mathbf{b})$, calcium $(\mathrm{Ca})(\mathbf{c})$, magnesium $(\mathrm{Mg})(\mathbf{d})$, iron $(\mathrm{Fe})$ (e), corticosterone (CORT) (f), thiobarbituric acid-reactive substances (TBARS) (g) and protein carbonyl content (PCC) (h) concentrations in serum. Values are expressed as the mean \pm SEM. Data were analyzed by Student's $t$ test. $* p<0.05, * * p<0.01, * * * p<0.001$ versus respective $\mathrm{ZnA}$. Statistical details: $\mathrm{Zn}[p<0.0001$, $t(18)=17.64], \mathrm{Cu}[p=0.8373, t(17)=0.2085], \mathrm{Ca}[p=0.0037$, $t(18)=3.329], \operatorname{Mg}[p=0.0002, t(18)=4.703]$, Fe $[p=0.0007$, $t(17)=4.112], \quad$ CORT $\quad[t(13)=3.924, \quad p=0.0017], \quad$ TBARS $[t(13)=5.260, p=0.0002]$, PCC $[t(10)=2.256, p=0.0477]$

(Fig. 3b) or PFC (Fig. 3g) between the $\mathrm{ZnD}$ and control animals. Similarly, the concentrations of calcium (Fig. 3c, h) or magnesium (Fig. 3d, i) in the Hp or PFC did not significantly differ between the $\mathrm{ZnA}$ and $\mathrm{ZnD}$ groups. TBARS (Fig. 4a), PCC (Fig. 4b), and IL-1 $\alpha$ (Fig. 4c) but not IL-1 $\beta$ (Fig. 4d) levels were significantly increased in the $\mathrm{Hp}$ of the $\mathrm{ZnD}$ rats at 4 weeks. The levels of TBARS (Fig. 4e) and IL-1 $\beta$ (Fig. 4h) were also significantly increased in the PFC of the $\mathrm{ZnD}$ group, but the levels of PCC (Fig. 4f) or IL-1 $\alpha$ (Fig. 4g) did not significantly differ in the PFC between the $\mathrm{ZnD}$ and $\mathrm{ZnA}$ animals at 4 weeks.
The Effects of a 6-week Dietary Zinc Restriction on $\mathrm{Zn}, \mathrm{Cu}, \mathrm{Ca}, \mathrm{Mg}$, Fe, CORT, and TBARS Levels in Serum

A 6-week $\mathrm{ZnD}$ diet significantly decreased serum zinc (Fig. 5a), increased iron (Fig. 5e) and CORT (Fig. 5f) concentrations, but did not significantly affect copper (Fig. 5b), calcium (Fig. 5c), magnesium (Fig. 5d), or TBARS (Fig. 5g) concentrations.

\section{The Effects of a 6-week Dietary Zinc Restriction on $\mathrm{Zn}, \mathrm{Fe}$, and TBARS Levels in the Hp and PFC}

At 6 weeks, there were no significant changes in zinc level in the Hp (Fig. 6a) or PFC (Fig. 6b) between the $\mathrm{ZnD}$ and control animals, whereas iron level was significantly increased in the PFC (Fig. 6d), but not in the Hp (Fig. 6c) of the $\mathrm{ZnD}$ rats. Furthermore, TBARS levels were significantly increased in both the Hp (Fig. 6e) and PFC (Fig. 6f) of the $\mathrm{ZnD}$ rats at 6 weeks.

\section{The Effects of a 6-week Dietary Zinc Restriction on Extracellular Zn, Fe, and Glutamate Levels in the PFC}

At 6 weeks, the extracellular zinc level in the PFC was significantly decreased in the $\mathrm{ZnD}$ group, compared to the $\mathrm{ZnA}$ group, after a 40-min stimulation with $100 \mathrm{mM} \mathrm{KCl}$ (Fig. 7c). The basal extracellular zinc level (Fig. 7a) or zinc level after a 20-min stimulation with $100 \mathrm{mM} \mathrm{KCl}$ (Fig. 7b) did not significantly differ between the $\mathrm{ZnD}$ and $\mathrm{ZnA}$ groups. The extracellular iron level was significantly increased in the PFC of the $\mathrm{ZnD}$ rats after a 20-min (Fig. 7e), but not after a 40-min stimulation (Fig. 7f). The basal extracellular iron level did not differ significantly between the $\mathrm{ZnD}$ and $\mathrm{ZnA}$ groups (Fig. 7d). Moreover, the basal extracellular glutamate level did not differ significantly between the $\mathrm{ZnD}$ and $\mathrm{ZnA}$ rats (Fig. $7 \mathrm{~g}$ ). However, after a 20- (Fig. 7h) or a 40-min (Fig. 7i) stimulation, the extracellular level of glutamate was significantly increased in the $\mathrm{PFC}$ of the $\mathrm{ZnD}$ group, compared to the $\mathrm{ZnA}$ group.

\section{Discussion}

We have previously shown that 4 or 6 weeks of the $\mathrm{ZnD}$ diet induces depression-like behavior with concomitant alterations within NMDAR signaling pathway (Doboszewska et al. 2015). In the present study, we measured bio-elements and oxidative/inflammatory parameters, which may be associated with depression/NMDAR function, in the $\mathrm{ZnD}$ rats. 


\section{4 weeks}
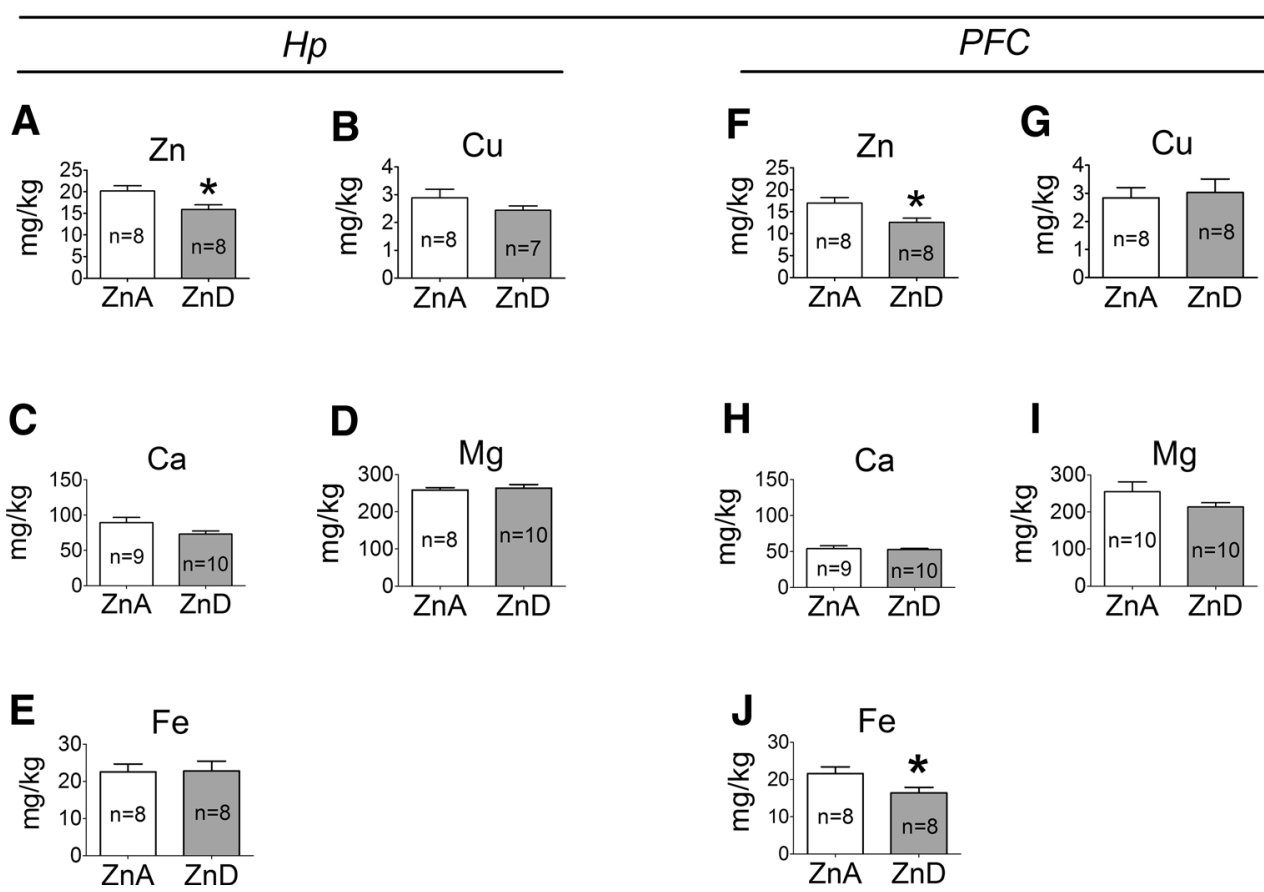

Fig. 3 The effects of a 4-week dietary zinc restriction on $\mathrm{Zn}(\mathbf{a}), \mathrm{Cu}$ (b), $\mathrm{Ca}(\mathbf{c}), \mathrm{Mg}$ (D), Fe (e) levels in the hippocampus (Hp) and on $\mathrm{Zn}$ (f), $\mathrm{Cu}(\mathbf{g}), \mathrm{Ca}(\mathbf{h}), \mathrm{Mg}(\mathbf{i}), \mathrm{Fe}(\mathbf{j})$ levels in the prefrontal cortex (PFC). Values are expressed as the mean \pm SEM. Data were analyzed by Student's $t$ test. ${ }^{*} p<0.05$ versus respective ZnA. Statistical details: $H p: \quad \mathrm{Zn} \quad[p=0.0199, \quad t(14)=2.628], \quad \mathrm{Cu} \quad[p=0.2402$,

$t(13)=1.232], \mathrm{Ca}[p=0.0777, t(17)=1.877], \operatorname{Mg}[p=0.6797$, $t(16)=0.4206], \quad \mathrm{Fe} \quad[p=0.9477, \quad t(14)=0.06674] . \quad P F C: \quad \mathrm{Zn}$ $[p=0.0154, t(14)=2.758], \mathrm{Cu}[p=0.7520, t(14)=0.3223], \mathrm{Ca}$ $[p=0.7024, t(17)=0.3886], \operatorname{Mg}[p=0.1787, t(18)=1.399], \mathrm{Fe}$ $[p=0.0397, t(14)=2.268]$

\section{4 weeks}

\begin{tabular}{|c|c|c|c|c|}
\hline \multicolumn{2}{|c|}{$H p$} & \multicolumn{3}{|c|}{ PFC } \\
\hline A & B & $E$ & $\mathbf{F}$ & \\
\hline 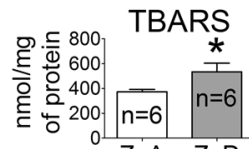 & 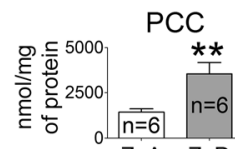 & 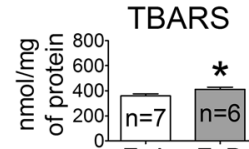 & 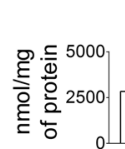 & 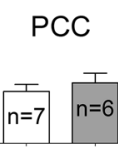 \\
\hline
\end{tabular}

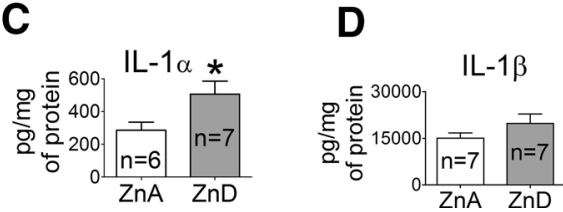

Fig. 4 The effects of a 4-week dietary zinc restriction on TBARS (a), PCC (b), interleukin-1 alpha (IL-1 $\alpha)(\mathbf{c})$, interleukin-1 beta (Il-1 $\beta$ ) (d) levels in the Hp and on TBARS (e), PCC (f), IL-1 $\alpha$ (g), Il-1 $\beta$ (h) levels in the PFC. Values are expressed as the mean \pm SEM. Data were analyzed by Student's $t$ test. $* p<0.05, * * p<0.01$ versus respective ZnA. Statistical details: $H p$ : TBARS [ $p=0.0499$,

We found lowered zinc level in the Hp and PFC of rats after a 4 -week $\mathrm{ZnD}$ diet. Most of the published work demonstrated no changes in total zinc level in brain regions
G

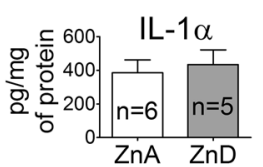

H

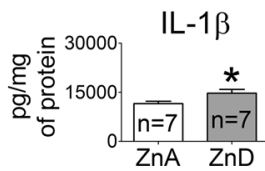

$t(10)=2.230], \quad$ PCC $\quad[p=0.0096, \quad t(10)=3.192], \quad$ IL-1 $\alpha$ $[p=0.0438, t(11)=2.277]$, IL-1 $\beta[p=0.1842, t(12)=1.409]$. $P F C$ : TBARS $[p=0.0443, t(11)=2.271]$, PCC $[p=0.4878$, $t(11)=0.7179], \quad$ IL-1 $\alpha \quad[p=0.6887, \quad t(9)=0.4138], \quad$ IL-1 $\beta$ $[p=0.0389, t(12)=2.318]$

following its chronic restriction (Takeda et al. 2003, 2005, 2008a), but decreased zinc level in the Hp in a response to dietary zinc deficiency has been previously reported 


\section{6 weeks - serum}
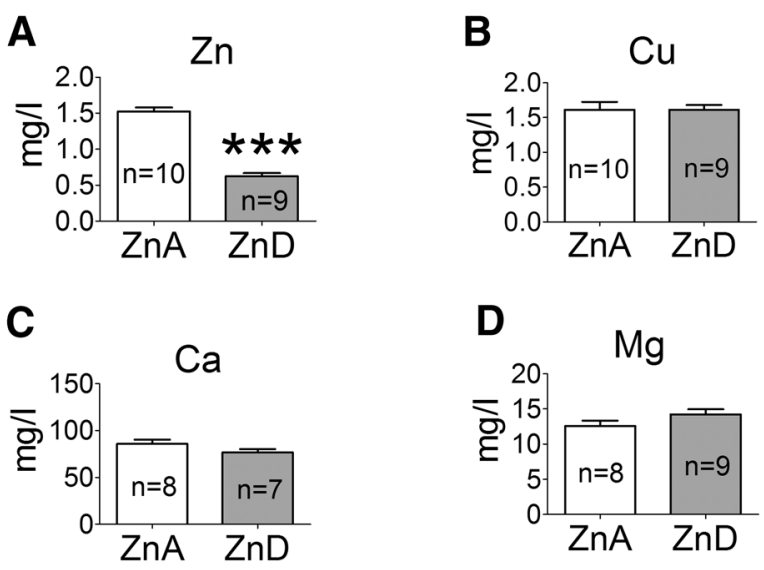

$\mathbf{E}$

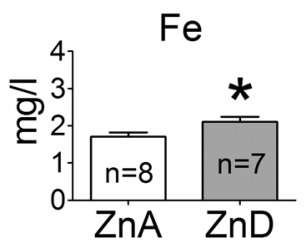

G

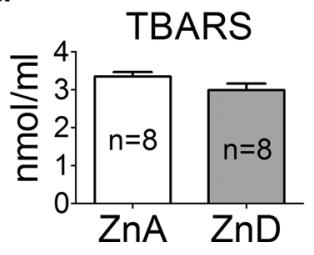

Fig. 5 The effects of a 6-week dietary zinc restriction on $\mathrm{Zn}(\mathbf{a}), \mathrm{Cu}$ (b), $\mathrm{Ca}(\mathbf{c}), \mathrm{Mg}(\mathbf{d}), \mathrm{Fe}(\mathbf{e}), \mathrm{CORT}(\mathbf{f})$, and TBARS (g) concentrations in serum. Values are expressed as the mean \pm SEM. Data were analyzed by Student's $t$ test. $* p<0.05, * * * p<0.001$ versus respective $\mathrm{ZnA}$. Statistical details: $\mathrm{Zn}[p<0.0001, t(17)=12.80]$, $\mathrm{Cu}[p=0.9929, t(17)=0.009016], \mathrm{Ca}[p=0.1231, t(13)=1.649]$, $\operatorname{Mg}[p=0.1452, t(15)=1.537], \mathrm{Fe}[p=0.0481, t(13)=2.181]$, CORT $[t(10)=2.490, \quad p=0.0320], \quad$ TBARS $[t(14)=1.661$, $p=0.1190]$

(Takeda et al. 2001). Because zinc released from presynaptic terminals of glutamatergic neurons in the cortex and Hp inhibits NMDAR on the postsynaptic side (Paoletti et al. 2009), the decrease in zinc content of these brain regions may have a consequence for NMDAR function and presumably the development of depression. The observation that the time-course of decreased zinc level in brain regions corresponds to the time of occurrence of depression-like behavior and up-regulation of NMDAR subunits (GluN2A, GluN2B) in the Hp of the $\mathrm{ZnD}$ rats, which was found in our previous study (Doboszewska et al. 2015) (Table 2), is consistent with this line of thinking.

Decreased hippocampal zinc level corresponding to depression-like behavior was found in rats exposed to
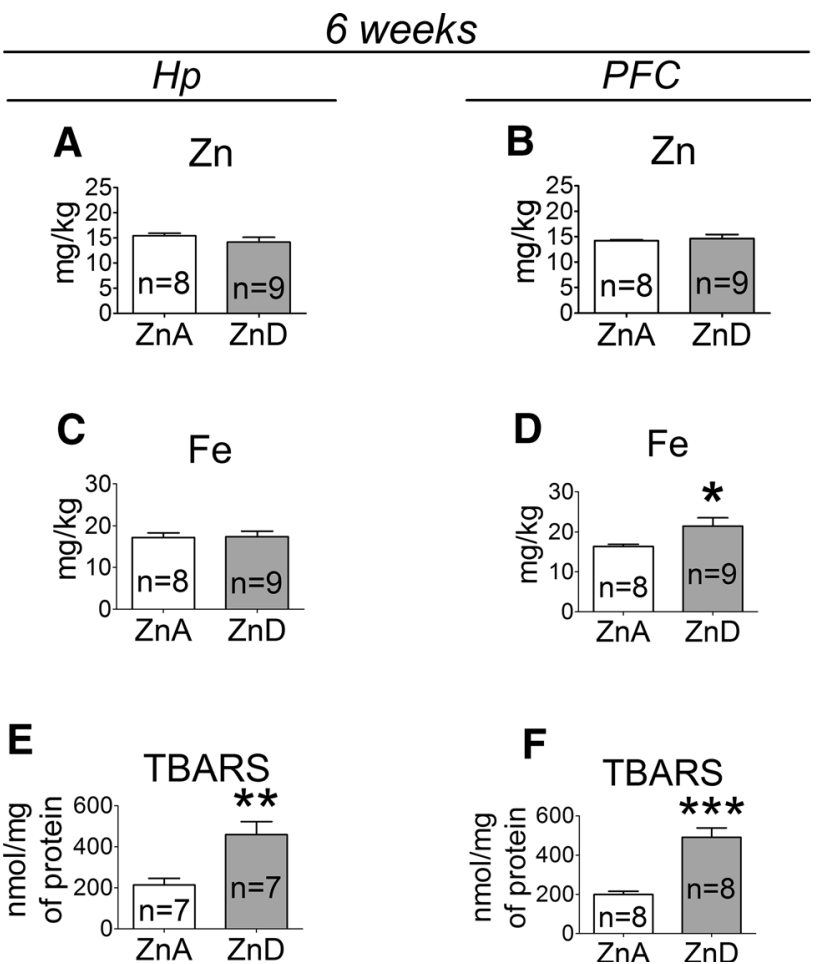

Fig. 6 The effects of a 6-week dietary zinc restriction on $\mathrm{Zn}(\mathbf{a}), \mathrm{Fe}$ (c), TBARS (e) levels in the Hp and on $\mathrm{Zn}(\mathbf{b}), \mathrm{Fe}(\mathbf{d})$ and TBARS (f) levels in the PFC. Values are expressed as the mean \pm SEM. Data were analyzed by Student's $t$ test. ${ }^{*} p<0.05, *^{*} p<0.01$, $* * * p<0.001$ versus respective $\mathrm{ZnA}$. Statistical details: Hp: Zn $[p=0.2708, \quad t(15)=1.143], \quad \mathrm{Fe}[p=0.9077, \quad t(15)=0.1180]$, TBARS $[p=0.0045, t(12)=3.491] . \quad P F C: \quad \mathrm{Zn} \quad[\mathrm{p}=0.6603$, $t(15)=0.4483], \quad \mathrm{Fe} \quad[p=0.0429, \quad t(15)=2.212], \quad$ TBARS $[p<0.0001, t(14)=5.751]$

psychological stress (Dou et al. 2014) and was associated with increased serum CORT concentration (Tao et al. 2013). Increased serum CORT was also demonstrated following zinc restriction (the present data, Watanabe et al. 1992; Chu et al. 2003; Takeda et al. 2007, 2008a, b, Takeda et al. 2012, Mlyniec et al. 2012). Thus, the $\mathrm{ZnD}$ diet induces changes in hippocampal zinc and serum CORT similar to those observed after exposure to stress, which is considered as a precipitant of depression.

The lack of differences between zinc level in the Hp or PFC of the $\mathrm{ZnD}$ and control rats after prolonged (a 6-week) deprivation suggests dynamic redistribution of the bioelement during its dietary regimen. It should be noted, however, that at 6 weeks of the $\mathrm{ZnD}$ diet, a concomitant decrease in evoked zinc release in the PFC was observed, which was accompanied by increased glutamate release (as measured by the in vivo microdialysis). Because we have previously found significantly increased level of NMDAR GluN2A protein in the PFC of rats at 6 weeks of zinc restriction (Doboszewska et al. 2015) (Table 2) (which indicates that a 6-week $\mathrm{ZnD}$ diet may alter the function of 


\section{6 weeks - PFC}
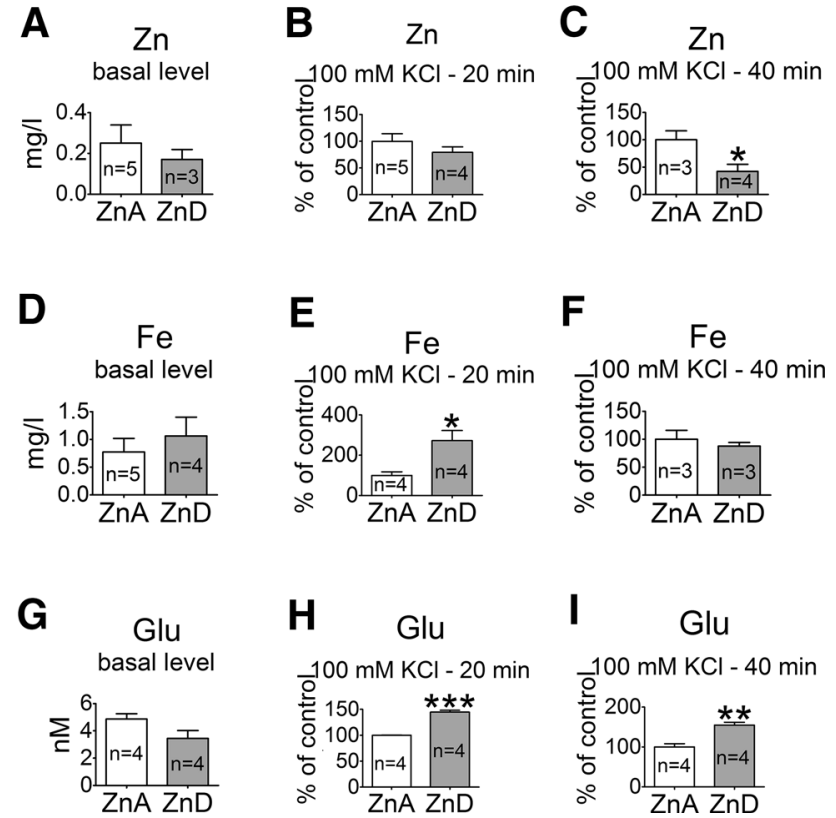

Fig. 7 The effects of a 6-week dietary zinc restriction on extracellular $\mathrm{Zn}, \mathrm{Fe}$, and glutamate (Glu) concentrations in the PFC: basal extracellular $\mathrm{Zn}$ level (a), extracellular $\mathrm{Zn}$ level after a 20-min stimulation with $100 \mathrm{mM} \mathrm{KCl} \mathrm{(b),} \mathrm{extracellular} \mathrm{Zn}$ level after a 40-min stimulation with $100 \mathrm{mM} \mathrm{KCl} \mathrm{(c);} \mathrm{basal} \mathrm{extracellular} \mathrm{Fe} \mathrm{level}$ (d), extracellular Fe level after a 20 -min stimulation with $100 \mathrm{mM}$ $\mathrm{KCl}$ (e), extracellular $\mathrm{Fe}$ level after a 40-min stimulation with $100 \mathrm{mM} \mathrm{KCl}(\mathbf{f})$; basal extracellular Glu level (g), extracellular Glu level after a 20 -min stimulation with $100 \mathrm{mM} \mathrm{KCl}(\mathbf{h})$, extracellular Glu level after a 40-min stimulation with $100 \mathrm{mM} \mathrm{KCl} \mathrm{(i).} \mathrm{Basal}$ extracellular levels are expressed as the mean \pm SEM. The extracellular levels after stimulations (mean \pm SEM) are presented as the \% of respective ZnA. Data were analyzed by Student's $t$ test. * $p<0.05$, $* * p<0.01, * * * p<0.001$ versus respective $\mathrm{ZnA}$. Statistical details: $\mathrm{Zn}$ basal level $[p=0.5389, t(6)=0.6515], \mathrm{Zn} 20$-min stimulation $[p=0.2983, t(7)=1.124)], \mathrm{Zn} 40-\min$ stimulation $[p=0.0386$, $t(5)=2.786]$, Fe basal level $[p=0.4922, t(7)=0.7125]$, Fe 20-min stimulation $[p=0.0168, t(6)=3.280], \quad \mathrm{Fe}$ 40-min stimulation $[p=0.5250, \quad t(4)=0.7036], \quad$ Glu basal level $[t(6)=2.046$, $p=0.0867]$, Glu 20-min stimulation $[t(6)=13.23, p<0.0001]$, Glu 40-min stimulation $[t(6)=4.901, p=0.0027]$
NMDAR in the PFC), our previous and present observations suggest that zinc deficiency may enhance glutamate signaling through NMDAR.

Reductions in protein expression of zinc transporter 3 (ZnT3) in Brodmann area 9 (which is a part of the frontal cortex) were shown to be significantly associated with elevated depression scores in patients with dementia with Lewy bodies (DLB), Parkinson disease dementia (PDD), and Alzheimer disease (AD) (Whitfield et al. 2015). Because in ZnT3 knockouts, synaptic zinc is undetectable (Cole et al. 1999), these data provide evidence for the role of decreased synaptic zinc in depression. Therefore, decreased evoked zinc release in the $\mathrm{PFC}$ of the $\mathrm{ZnD}$ rats, suggesting decreased level of synaptic zinc, may be linked to depression-like behavior in the zinc deficiency paradigm.

In the present study, the 4-week $\mathrm{ZnD}$ diet reduced iron content of the PFC, whereas an increase in iron content of the PFC was observed after the 6-week $\mathrm{ZnD}$ diet. Iron deficiency may lead to abnormal mood and behavior (Kim and Wessling-Resnick. 2014). On the other hand, iron progressively accumulates in the brain with aging (Bilgic et al. 2012; Ramos et al. 2014) and its accumulation in the brain has been implicated in the etiology of numerous neurodegenerative disorders (Schipper 2012; Zheng and Monnot 2012). There is evidence that depression is accompanied by a progressive process of neurodegeneration (Szewczyk et al. 2011; Maes et al. 2012b; Smaga et al. 2014). Magnetic resonance imaging studies in elderly depressed patients have shown that an older age of onset and a greater severity of depression are associated with increased iron deposition in specific brain regions (Steffens et al. 1998). Moreover, exposure to psychological stress was found to increase iron level in the cortex and $\mathrm{Hp}$ (Wang et al. 2008; Yu et al. 2011), whereas zinc supplementation was found to decrease iron deposition in the cortex and Hp induced by psychological stress (Li et al. 2012). Thus, the increase in iron level in the brain may be a common effect of prolonged zinc deficiency, psychological stress, and depression.

Table 2 Summary of previous findings on the zinc deficiency model in rats

\begin{tabular}{lll}
\hline & 4 weeks & 6 weeks \\
\hline Behavioral parameters & Increased immobility time in the forced swim test (FST) & Increased immobility time in the FST \\
& Anhedonia & Anhedonia \\
& Reduction of social behavior & Reduction of social behavior \\
Protein levels & $H p: \uparrow$ GluN2A, $\uparrow$ GluN2B, $\downarrow \mathrm{p}-\mathrm{CREB}, \downarrow \mathrm{BDNF}$ & $H p: \uparrow$ GluN2A, $\uparrow \mathrm{GluN} 2 \mathrm{~B}, \downarrow \mathrm{p}-\mathrm{CREB}, \downarrow \mathrm{BDNF}$ \\
& $P F C: \leftrightarrow \mathrm{GluN} 2 \mathrm{~A}, \leftrightarrow \mathrm{GluN} 2 \mathrm{~B}, \leftrightarrow \mathrm{p}-\mathrm{CREB}, \leftrightarrow \mathrm{BDNF}$ & $P F C: \uparrow$ GluN2A, $\leftrightarrow \mathrm{GluN} 2 \mathrm{~B}, \downarrow \mathrm{p}-\mathrm{CREB}, \downarrow \mathrm{BDNF}$
\end{tabular}

Rats were fed a $\mathrm{ZnA}$ or a $\mathrm{ZnD}$ diet for 4 or 6 weeks. GluN2A, GluN2B-subunits of the glutamate $N$-methyl-D-aspartate receptor; $p$-CREBphosphorylated cyclic AMP response element-binding protein; BDNF-brain-derived neurotrophic factor; $\uparrow$-increased protein level; $\downarrow$ decreased protein level; $\leftrightarrow$ no effects. Based on Doboszewska et al. 2015 
As mentioned above, we have previously found significantly increased level of NMDAR GluN2A protein in the PFC of rats after the 6-week $\mathrm{ZnD}$ diet; however, no differences in the levels of NMDAR GluN2A or GluN2B proteins were observed in the PFC between the $\mathrm{ZnD}$ and control animals after the 4-week $\mathrm{ZnD}$ diet (Doboszewska et al. 2015) (Table 2). These data, together with the present data concerning increased glutamate release after 6 weeks of the $\mathrm{ZnD}$ diet administration, indicate that prolonged (6 weeks) zinc restriction may lead to activation of NMDAR in the PFC. It has been demonstrated that the stimulation of NMDAR induces iron uptake (Cheah et al. 2006). This mechanism may explain iron accumulation in the PFC of rats after 6 weeks, but not after 4 weeks of zinc deprivation. Moreover, at 6 weeks, but not at 4 weeks, we found decreased brain-derived neurotrophic factor (BDNF) protein expression in the PFC of the $\mathrm{ZnD}$ rats (Doboszewska et al. 2015) (Table 2). BDNF can ameliorate iron accumulation in neurons (Zhang et al. 2014). Thus, increased iron level in the PFC of rats at 6 weeks might result from decreased level of BDNF.

In addition to decreased zinc release, increased evoked iron release was observed in the PFC of the $\mathrm{ZnD}$ rats. Iron transporter ferroportin was found to be expressed in synaptic vesicles (Wu et al. 2004); however, iron homeostasis in the brain has not been clearly defined (Ward et al. 2014). Presumably, the presence of iron in extracellular space may induce oxidative stress.

Moreover, both the 4- and the 6-week $\mathrm{ZnD}$ diets lowered serum zinc and increased serum iron concentrations. Data concerning the relationship between depression and serum iron concentration are inconsistent (Maes et al. 1996; Rybka et al. 2013). In contrast, decreased serum zinc level associated with depression has been repeatedly observed (Siwek et al. 2013b) and has been demonstrated through a meta-analysis of clinical studies (Swardfager et al. 2013). The altered levels of magnesium and calcium in serum following zinc depletion suggest redistribution of these elements after dietary zinc regimen, although peripheral alterations were in the present study not accompanied by central alterations. In this study, the 4-week $\mathrm{ZnD}$ diet increased serum magnesium concentration. In animal models of depression based on stress exposure and in olfactory bulbectomy model, no differences in serum magnesium levels were demonstrated (Zieba et al. 2000); however, higher serum magnesium concentrations have been reported in depressed patients, compared to healthy controls, yet the data are not consistent (Serefko et al. 2013). Lowered level of magnesium in the Hp was recently shown in post-mortem study of suicide subjects (Sowa-Kucma et al. 2013).

Also, data regarding the relationship between serum copper concentration and depression are not consistent, but higher serum copper levels in patients suffering from depression have been reported (Manser et al. 1989; Schlegel-Zawadzka et al. 1999). In the present study, we did not observe differences in copper levels either in serum or brain tissues. Likewise, the study of zinc deficiency in mice, which demonstrated depression-like behavior and decreased serum zinc level, did not show differences in serum copper levels (Mlyniec et al. 2014b).

Associations between the increase in the lipid (TBARS) and protein (PCC) oxidation, pro-inflammatory cytokine (IL- $1 \alpha$ and $\beta$ ) levels, decrease of zinc, and increase of iron levels have been noted previously in in vivo (Arruda et al. 2013; Mehrpouya et al. 2015) and in vitro/cell culture (Tate et al. 1999; Wessels et al. 2013) experiments. Moreover, a link of depression-like behavior with the enhancement of oxidative stress/pro-inflammatory status and with iron content in other experimental models and in clinical studies (Wayhs et al. 2010; Lopresti et al. 2014; Spanemberg et al. 2014; Mehrpouya et al. 2015; Tsai and Huang. 2015) was demonstrated. Increased oxidative stress as well as proinflammatory cytokines may lead to NMDAR activation (Leonard and Maes. 2012; Maes et al. 2012a; Felger and Lotrich 2013; Myint and Kim 2014). Furthermore, a mixture of pro-inflammatory cytokines, containing IL-1 $\beta$, was shown to increase glutamate release (Ida et al. 2008), whereas administration of IL-1 $\beta$ induced depression-like behavior (Maes et al. 2012a). Thus, increased levels of proinflammatory cytokines and enhancement of oxidation in the $\mathrm{Hp}$ and PFC of the $\mathrm{ZnD}$ rats may contribute to increased release of glutamate, NMDAR activation, and depression-like behavior.

\section{Conclusions}

Dietary zinc restriction induces peripheral and central alterations of bio-elements (namely zinc and iron) and enhances oxidative damage and pro-inflammatory status. These alterations share some similarities to those observed after exposure to stress and in depression, which further highlights that zinc deficiency [recently proposed as a model of depression (Whittle et al. 2009; Mlyniec et al. 2013; Doboszewska et al. 2015)] and depression may share a common pathophysiology. The changes observed in the present study may have a link to depression-like behavior in the zinc deficiency paradigm and may lead to/result from enhanced glutamate transmission through NMDAR.

Acknowledgments The study was partially supported by the project Interdisciplinary $\mathrm{PhD}$ Studies "Molecular sciences for medicine" (cofinanced by the European Social Fund within the Human Capital Operational Programme), Grant POIG.01.01.02-12-004/09-00, and Statutory Activity of the Institute of Pharmacology PAS and Jagiellonian University Medical College in Kraków. 


\section{Compliance with Ethical Standards}

Funding The study was funded by the project Interdisciplinary $\mathrm{PhD}$ Studies "Molecular sciences for medicine" (co-financed by the European Social Fund within the Human Capital Operational Programme), Grant POIG.01.01.02-12-004/09-00, and Statutory Activity of the Institute of Pharmacology PAS and Jagiellonian University Medical College in Kraków.

Conflict of Interest The authors declare that they have no conflict of interest.

Open Access This article is distributed under the terms of the Creative Commons Attribution 4.0 International License (http://crea tivecommons.org/licenses/by/4.0/), which permits unrestricted use, distribution, and reproduction in any medium, provided you give appropriate credit to the original author(s) and the source, provide a link to the Creative Commons license, and indicate if changes were made.

\section{References}

Arruda LF, Arruda SF, Campos NA, de Valencia FF, Siqueira EM (2013) Dietary iron concentration may influence aging process by altering oxidative stress in tissues of adult rats. PLoS One 8:e61058. doi:10.1371/journal.pone.0061058

Bilgic B, Pfefferbaum A, Rohlfing T, Sullivan EV, Adalsteinsson E (2012) MRI estimates of brain iron concentration in normal aging using quantitative susceptibility mapping. Neuroimage 59:2625-2635. doi:10.1016/j.neuroimage.2011.08.077

Bonaventura P, Benedetti G, Albarede F, Miossec P (2015) Zinc and its role in immunity and inflammation. Autoimmun Rev 14:277-285. doi:10.1016/j.autrev.2014.11.008

Cheah JH, Kim SF, Hester LD, Clancy KW, Patterson SE III, Papadopoulos V, Snyder SH (2006) NMDA receptor-nitric oxide transmission mediates neuronal iron homeostasis via the GTPase Dexras1. Neuron 51:431-440

Chu Y, Mouat MF, Harris RB, Coffield JA, Grider A (2003) Water maze performance and changes in serum corticosterone levels in zinc-deprived and pair-fed rats. Physiol Behav 78:569-578

Cole TB, Wenzel HJ, Kafer KE, Schwartzkroin PA, Palmiter RD (1999) Elimination of zinc from synaptic vesicles in the intact mouse brain by disruption of the ZnT3 gene. Proc Natl Acad Sci 96:1716-1721

Dinarello CA, Simon A, van der Meer JW (2012) Treating inflammation by blocking interleukin-1 in a broad spectrum of diseases. Nat Rev Drug Discov 11:633-652. doi:10.1038/ $\operatorname{nrd} 3800$

Doboszewska U, Sowa-Kucma M, Mlyniec K, Pochwat B, Holuj M, Ostachowicz B, Pilc A, Nowak G, Szewczyk B (2015) Zinc deficiency in rats is associated with up-regulation of hippocampal NMDA receptor. Prog Neuropsychopharmacol Biol Psychiatry 56:254-263. doi:10.1016/j.pnpbp.2014.09.013

Dou X, Tian X, Zheng Y, Huang J, Shen Z, Li H, Wang X, Mo F, Wang W, Wang S, Shen H (2014) Psychological stress induced hippocampus zinc dyshomeostasis and depression-like behavior in rats. Behav Brain Res 273C:133-138

Felger JC, Lotrich FE (2013) Inflammatory cytokines in depression: neurobiological mechanisms and therapeutic implications. Neuroscience 246:199-229. doi:10.1016/j.neuroscience.2013.04.060

Ghasemi M, Phillips C, Trillo L, De Miguel Z, Das D, Salehi A (2014) The role of NMDA receptors in the pathophysiology and treatment of mood disorders. Neurosci Biobehav Rev 47C:336-358
Hagmeyer S, Haderspeck JC, Grabrucker AM (2015) Behavioral impairments in animal models for zinc deficiency. Front Behav Neurosci 8:443. doi:10.3389/fnbeh.2014.00443

Ida T, Hara M, Nakamura Y, Kozaki S, Tsunoda S, Ihara H (2008) Cytokine-induced enhancement of calcium-dependent glutamate release from astrocytes mediated by nitric oxide. Neurosci Lett 432:232-236. doi:10.1016/j.neulet.2007.12.047

Jurowski K, Szewczyk B, Nowak G, Piekoszewski W (2014) Biological consequences of zinc deficiency in the pathomechanisms of selected diseases. J Biol Inorg Chem 19:1069-1079. doi:10.1007/s00775-014-1139-0

Kim J, Wessling-Resnick M (2014) Iron and mechanisms of emotional behavior. J Nutr Biochem 25:1101-1107

Kopanski Z, Schlegel-Zawadzka M, Piekoszewski W, Sadlik K, Sibiga W (2000) The disturbances of magnesium in patients with thromboembolic complications after a cholecystectomy. Thromb Res 99:571-575

Leonard B, Maes M (2012) Mechanistic explanations how cellmediated immune activation, inflammation and oxidative and nitrosative stress pathways and their sequels and concomitants play a role in the pathophysiology of unipolar depression. Neurosci Biobehav Rev 36:764-785. doi:10.1016/j.neubiorev. 2011.12.005

Li Y, Zheng Y, Qian J, Chen X, Shen Z, Tao L, Li H, Qin H, Li M, Shen H (2012) Preventive effects of zinc against psychological stress-induced iron dyshomeostasis, erythropoiesis inhibition, and oxidative stress status in rats. Biol Trace Elem Res 147:285-291. doi:10.1007/s12011-011-9319-z

Lopresti AL, Maker GL, Hood SD, Drummond PD (2014) A review of peripheral biomarkers in major depression: the potential of inflammatory and oxidative stress biomarkers. Prog Neuropsychopharmacol Biol Psychiatry 48:102-111. doi:10.1016/j.pnpbp. 2013.09.017

Maes M, Van de Vyvere J, Vandoolaeghe E, Bril T, Demedts P, Wauters A, Neels H (1996) Alterations in iron metabolism and the erythron in major depression: further evidence for a chronic inflammatory process. J Affect Disord 40:23-33

Maes M, Fisar Z, Medina M, Scapagnini G, Nowak G, Berk M (2012a) New drug targets in depression: inflammatory, cellmediated immune, oxidative and nitrosative stress, mitochondrial, antioxidant, and neuroprogressive pathways. And new drug candidates-Nrf2 activators and GSK-3 inhibitors. Inflammopharmacology 20:127-150. doi:10.1007/s10787-011-0111-7

Maes M, Fisar Z, Medina M, Scapagnini G, Nowak G, Berk M (2012b) New drug targets in depression: inflammatory, cellmediated immune, oxidative and nitrosative stress, mitochondrial, antioxidant, and neuroprogressive pathways. And new drug candidates-Nrf2 activators and GSK-3 inhibitors. Inflammopharmacology 20:127-150. doi:10.1007/s10787-011-0111-7

Manser WW, Khan MA, Hasan KZ (1989) Trace element studies on Karachi population. Part IV: blood copper, zinc, magnesium and lead levels in psychiatric patients with depression, mental retardation and seizure disorders. J Pak Med Assoc 39:269-274

Marsden WN (2011) Stressor-induced NMDAR dysfunction as a unifying hypothesis for the aetiology, pathogenesis and comorbidity of clinical depression. Med Hypotheses 77:508-528. doi:10.1016/j.mehy.2011.06.021

Mayer ML, Westbrook GL (1987) Permeation and block of $\mathrm{N}$-methyl-D-aspartic acid receptor channels by divalent cations in mouse cultured central neurones. J Physiol 394:501-527

Mehrpouya S, Nahavandi A, Khojasteh F, Soleimani M, Ahmadi M, Barati M (2015) Iron administration prevents BDNF decrease and depressive-like behavior following chronic stress. Brain Res 1596:79-87. doi:10.1016/j.brainres.2014.10.057

Mlyniec K, Davies CL, Budziszewska B, Opoka W, Reczynski W, Sowa-Kucma M, Doboszewska U, Pilc A, Nowak G (2012) 
Time course of zinc deprivation-induced alterations of mice behavior in the forced swim test. Pharmacol Rep 64:567-575

Mlyniec K, Budziszewska B, Reczynski W, Sowa-Kucma M, Nowak $G$ (2013) The role of the GPR39 receptor in zinc deficientanimal model of depression. Behav Brain Res 238:30-35. doi:10.1016/j.bbr.2012.10.020

Mlyniec K, Davies CL, de Aguero Sanchez IG, Pytka K, Budziszewska B, Nowak G (2014a) Essential elements in depression and anxiety. Part I. Pharmacol Rep 66:534-544. doi:10.1016/j.pharep.2014.03.001

Mlyniec K, Ostachowicz B, Krakowska A, Reczynski W, Opoka W, Nowak G (2014b) Chronic but not acute antidepresant treatment alters serum zinc/copper ratio under pathological/zinc-deficient conditions in mice. J Physiol Pharmacol 65:673-678

Mlyniec K, Gawel M, Doboszewska U, Starowicz G, Pytka K, Davies CL, Budziszewska B (2015) Essential elements in depression and anxiety. Part II. Pharmacol Rep 67:187-194. doi:10.1016/j. pharep.2014.09.009

Moylan S, Berk M, Dean OM, Samuni Y, Williams LJ, O’Neil A, Hayley AC, Pasco JA, Anderson G, Jacka FN, Maes M (2014) Oxidative and nitrosative stress in depression: why so much stress? Neurosci Biobehav Rev 45:46-62. doi:10.1016/j.neu biorev.2014.05.007

Myint AM, Kim YK (2014) Network beyond IDO in psychiatric disorders: revisiting neurodegeneration hypothesis. Prog Neuropsychopharmacol Biol Psychiatry 48:304-313. doi:10.1016/j. pnpbp.2013.08.008

Nakamichi N, Ohno H, Nakamura Y, Hirai T, Kuramoto N, Yoneda Y (2002) Blockade by ferrous iron of $\mathrm{Ca}^{2+}$ influx through $\mathrm{N}$-methyl-D-aspartate receptor channels in immature cultured rat cortical neurons. J Neurochem 83:1-11

Opoka W, Sowa-Kucma M, Stachowicz K, Ostachowicz B, Szlosarczyk M, Stypula A, Mlyniec K, Maslanka A, Bas B, Lankosz M, Nowak G (2010) Early lifetime zinc supplementation protects zincdeficient diet-induced alterations. Pharmacol Rep 62:1211-1217

Oteiza PI (2012) Zinc and the modulation of redox homeostasis. Free Radic Biol Med 53:1748-1759. doi:10.1016/j.freeradbiomed. 2012.08.568

Paoletti P, Vergnano AM, Barbour B, Casado M (2009) Zinc at glutamatergic synapses. Neuroscience 158:126-136. doi:10. 1016/j.neuroscience.2008.01.061

Paxinos G, Watson C (1998) The rat brain in stereotaxic coordinates, 4th edn. Academic Press, San Diego

Prasad AS (2012) Discovery of human zinc deficiency: 50 years later. J Trace Elem Med Biol 26:66-69. doi:10.1016/j.jtemb.2012.04. 004

Prasad AS (2014) Zinc is an antioxidant and anti-inflammatory agent: its role in human health. Front Nutr 1:14. doi:10.3389/fnut.2014. 00014

Ramos P, Santos A, Pinto NR, Mendes R, Magalhaes T, Almeida A (2014) Iron levels in the human brain: a post-mortem study of anatomical region differences and age-related changes. J Trace Elem Med Biol 28:13-17. doi:10.1016/j.jtemb.2013.08.001

Rybka J, Kedziora-Kornatowska K, Banas-Lezanska P, Majsterek I, Carvalho LA, Cattaneo A, Anacker C, Kedziora J (2013) Interplay between the pro-oxidant and antioxidant systems and proinflammatory cytokine levels, in relation to iron metabolism and the erythron in depression. Free Radic Biol Med 63:187-194. doi:10.1016/j.freeradbiomed.2013.05.019

Sanacora G, Treccani G, Popoli M (2012) Towards a glutamate hypothesis of depression: an emerging frontier of neuropsychopharmacology for mood disorders. Neuropharmacology 62:63-77. doi:10.1016/j.neuropharm.2011.07.036

Schipper HM (2012) Neurodegeneration with brain iron accumulation-clinical syndromes and neuroimaging. Biochim Biophys Acta 1822:350-360. doi:10.1016/j.bbadis.2011.06.016
Schlegel-Zawadzka M, Zieba A, Dudek D, Zak-Knapik J, Nowak G (1999) Is serum copper a "trait marker" of unipolar depression? A preliminary clinical study. Pol J Pharmacol 51:535-538

Serefko A, Szopa A, Wlaz P, Nowak G, Radziwon-Zaleska M, Skalski M, Poleszak E (2013) Magnesium in depression. Pharmacol Rep 65:547-554

Siwek M, Sowa-Kucma M, Dudek D, Styczen K, Szewczyk B, Kotarska K, Misztakk P, Pilc A, Wolak M, Nowak G (2013a) Oxidative stress markers in affective disorders. Pharmacol Rep 65:1558-1571

Siwek M, Szewczyk B, Dudek D, Styczen K, Sowa-Kucma M, Mlyniec K, Siwek A, Witkowski L, Pochwat B, Nowak G (2013b) Zinc as a marker of affective disorders. Pharmacol Rep 65:1512-1518

Smaga I, Krzyżanowska W, Pomierny B, Budziszewska B, Pilc A, Nowak G (2014) The role of neurotoxicity in depression. In: Kostrzewa RM (eds) Handbook of neurotoxicity. SpringerVerlag, New York, pp 1567-1593

Sowa-Kucma M, Szewczyk B, Sadlik K, Piekoszewski W, Trela F, Opoka W, Poleszak E, Pilc A, Nowak G (2013) Zinc, magnesium and NMDA receptor alterations in the hippocampus of suicide victims. J Affect Disord 151:924-931. doi:10.1016/j. jad.2013.08.009

Spanemberg L, Caldieraro MA, Vares EA, Wollenhaupt-Aguiar B, Kauer-Sant'Anna M, Kawamoto SY, Galvao E, Parker G, Fleck MP (2014) Biological differences between melancholic and nonmelancholic depression subtyped by the CORE measure. Neuropsychiatr Dis Treat 10:1523-1531. doi:10.2147/NDT. S66504

Steffens DC, Tupler LA, Ranga K, Krishnan R (1998) Magnetic resonance imaging signal hypointensity and iron content of putamen nuclei in elderly depressed patients. Psychiatry Res 83:95-103

Stys PK, You H, Zamponi GW (2012) Copper-dependent regulation of NMDA receptors by cellular prion protein: implications for neurodegenerative disorders. J Physiol 590:1357-1368. doi:10. 1113/jphysiol.2011.225276

Summersgill H, England H, Lopez-Castejon G, Lawrence CB, Luheshi NM, Pahle J, Mendes P, Brough D (2014) Zinc depletion regulates the processing and secretion of IL-1beta. Cell Death Dis 5:e1040. doi:10.1038/cddis.2013.547

Swardfager W, Herrmann N, Mazereeuw G, Goldberger K, Harimoto T, Lanctot KL (2013) Zinc in depression: a meta-analysis. Biol Psychiatry 74:872-878. doi:10.1016/j.biopsych.2013.05.008

Szewczyk B (2013) Zinc homeostasis and neurodegenerative disorders. Front Aging Neurosci 5:33. doi:10.3389/fnagi.2013.00033

Szewczyk B, Kubera M, Nowak G (2011) The role of zinc in neurodegenerative inflammatory pathways in depression. Prog Neuropsychopharmacol Biol Psychiatry 35:693-701. doi:10. 1016/j.pnpbp.2010.02.010

Szewczyk B, Palucha-Poniewiera A, Poleszak E, Pilc A, Nowak G (2012) Investigational NMDA receptor modulators for depression. Expert Opin Investig Drugs 21:91-102. doi:10.1517/ 13543784.2012.638916

Takeda A, Minami A, Takefuta S, Tochigi M, Oku N (2001) Zinc homeostasis in the brain of adult rats fed zinc-deficient diet. J Neurosci Res 63:447-452

Takeda A, Hirate M, Tamano H, Oku N (2003) Release of glutamate and GABA in the hippocampus under zinc deficiency. J Neurosci Res 72:537-542. doi:10.1002/jnr.10600

Takeda A, Tamano H, Tochigi M, Oku N (2005) Zinc homeostasis in the hippocampus of zinc-deficient young adult rats. Neurochem Int 46:221-225. doi:10.1016/j.neuint.2004.10.003

Takeda A, Tamano H, Kan F, Itoh H, Oku N (2007) Anxiety-like behavior of young rats after 2 -week zinc deprivation. Behav Brain Res 177:1-6. doi:10.1016/j.bbr.2006.11.023 
Takeda A, Tamano H, Kan F, Hanajima T, Yamada K, Oku N (2008a) Enhancement of social isolation-induced aggressive behavior of young mice by zinc deficiency. Life Sci 82:909-914. doi:10. 1016/j.lfs.2008.02.005

Takeda A, Yamada K, Tamano H, Fuke S, Kawamura M, Oku N (2008b) Hippocampal calcium dyshomeostasis and long-term potentiation in 2-week zinc deficiency. Neurochem Int 52:241-246

Takeda A, Tamano H, Ogawa T, Takada S, Ando M, Oku N, Watanabe M (2012) Significance of serum glucocorticoid and chelatable zinc in depression and cognition in zinc deficiency. Behav Brain Res 226:259-264. doi:10.1016/j.bbr.2011.09.026

Tao L, Zheng Y, Shen Z, Li Y, Tian X, Dou X, Qian J, Shen H (2013) Psychological stress-induced lower serum zinc and zinc redistribution in rats. Biol Trace Elem Res 155:65-71. doi:10.1007/ s12011-013-9762-0

Tate DJ Jr, Miceli MV, Newsome DA (1999) Zinc protects against oxidative damage in cultured human retinal pigment epithelial cells. Free Radic Biol Med 26:704-713

Tsai MC, Huang TL (2015) Thiobarbituric acid reactive substances (TBARS) is a state biomarker of oxidative stress in bipolar patients in a manic phase. J Affect Disord 173:22-26. doi:10. 1016/j.jad.2014.10.045

Vashum KP, McEvoy M, Milton AH, McElduff P, Hure A, Byles J, Attia J (2014) Dietary zinc is associated with a lower incidence of depression: findings from two Australian cohorts. J Affect Disord 166:249-257. doi:10.1016/j.jad.2014.05.016

Vlachova V, Zemkova H, Vyklicky L Jr (1996) Copper modulation of NMDA responses in mouse and rat cultured hippocampal neurons. Eur J Neurosci 8:2257-2264

Wang L, Wang W, Zhao M, Ma L, Li M (2008) Psychological stress induces dysregulation of iron metabolism in rat brain. Neuroscience 155:24-30. doi:10.1016/j.neuroscience.2008.03.091

Ward RJ, Zucca FA, Duyn JH, Crichton RR, Zecca L (2014) The role of iron in brain ageing and neurodegenerative disorders. Lancet Neurol 13:1045-1060. doi:10.1016/S1474-4422(14)70117-6

Watanabe M, Inoue Y, Sakimura K, Mishina M (1992) Developmental changes in distribution of NMDA receptor channel subunit mRNAs. NeuroReport 3:1138-1140

Wayhs CA, Manfredini V, Sitta A, Deon M, Ribas G, Vanzin C, Biancini G, Ferri M, Nin M, Barros HM, Vargas CR (2010) Protein and lipid oxidative damage in streptozotocin-induced diabetic rats submitted to forced swimming test: the insulin and clonazepam effect. Metab Brain Dis 25:297-304. doi:10.1007/ s11011-010-9211-0

Wessels I, Haase H, Engelhardt G, Rink L, Uciechowski P (2013) Zinc deficiency induces production of the proinflammatory cytokines IL-1beta and TNFalpha in promyeloid cells via epigenetic and redox-dependent mechanisms. J Nutr Biochem 24:289-297. doi:10.1016/j.jnutbio.2012.06.007

Whitfield DR, Vallortigara J, Alghamdi A, Hortobagyi T, Ballard C, Thomas AJ, O'Brien JT, Aarsland D, Francis PT (2015) Depression and synaptic zinc regulation in Alzheimer disease, dementia with lewy bodies, and Parkinson disease dementia. Am J Geriatr Psychiatry 23:141-148. doi:10.1016/j.jagp.2014.05.001

Whittle N, Lubec G, Singewald N (2009) Zinc deficiency induces enhanced depression-like behaviour and altered limbic activation reversed by antidepressant treatment in mice. Amino Acids 36:147-158. doi:10.1007/s00726-008-0195-6

Wu LJ, Leenders AG, Cooperman S, Meyron-Holtz E, Smith S, Land W, Tsai RY, Berger UV, Sheng ZH, Rouault TA (2004) Expression of the iron transporter ferroportin in synaptic vesicles and the blood-brain barrier. Brain Res 1001:108-117. doi:10. 1016/j.brainres.2003.10.066

Yu S, Feng Y, Shen Z, Li M (2011) Diet supplementation with iron augments brain oxidative stress status in a rat model of psychological stress. Nutrition 27:1048-1052. doi:10.1016/j. nut.2010.11.007

Zhang HY, Song N, Jiang H, Bi MX, Xie JX (2014) Brain-derived neurotrophic factor and glial cell line-derived neurotrophic factor inhibit ferrous iron influx via divalent metal transporter 1 and iron regulatory protein 1 regulation in ventral mesencephalic neurons. Biochim Biophys Acta 1843:2967-2975. doi:10.1016/j. bbamcr.2014.09.010

Zheng W, Monnot AD (2012) Regulation of brain iron and copper homeostasis by brain barrier systems: implication in neurodegenerative diseases. Pharmacol Ther 133:177-188. doi:10.1016/ j.pharmthera.2011.10.006

Zieba A, Kata R, Dudek D, Schlegel-Zawadzka M, Nowak G (2000) Serum trace elements in animal models and human depression: part III. Magnesium. Relationship with copper. Hum Psychopharmacol 15:631-635. doi:10.1002/hup.231 